\title{
The Effectiveness of Collaborative Learning to Enhance English Communicative Competence: A Case Study of the First-Year Students at Thepsatri Rajabhat University
}

\author{
Rodphotong, $\mathbf{S} .^{1}$ \\ ${ }^{1}$ Department of English, Faculty of Humanities and Social Sciences, \\ Thepsatri Rajabhat University, Lop Buri, Thailand \\ Corresponding email: sasilak.r@hotmail.com
}

\begin{abstract}
The attempts of the present study aimed at investigating the effectiveness of collaborative learning to enhance English communicative competence and evaluating students' satisfaction towards the instruction. The participants in this study were 1,471 the first-year students enrolled in the first semester, 2017 academic year. The students' English proficiency according to the CEFR was A1. The instruments used were lesson plans, pre-test and post-test and satisfaction questionnaire. The lessons were comprised of various collaborative learning activities emphasizing at the following topics: self-introduction, school schedule, telling time, asking and giving information, food, leisure, describing people, describing things and giving direction. The period of experiment was 20 hours. The independent sample t-test was calculated to find the differences. The findings revealed that there were statistically significant differences at the level of .01 after teaching with collaborative learning. This indicated that the students' communicative competence significantly improved. Besides, the satisfaction questionnaire was distributed at the end of the instruction and the results indicated that the students had a positive satisfaction towards the instruction.
\end{abstract}

Keywords: english language; collaborative learning; communicative competence

DOI: $10.20961 /$ ijpte.v\%vi\%i.25174 


\section{INTRODUCTION}

As we use language to communicate with other people in different countries, English is commonly used as lingua franca for connecting people around the world (Crystal, 2012). In Thailand, English has therefore been taught for years; however, the problems of using English in class still occurs. Srikote (2003) states that there are two major problems that can be obviously seen. The first one is many teachers in Thailand employ a teacher-centered approach, which requires Thai students to listen to teachers' lectures, and the other problem is that Thai students do not have any opportunities to use English in their real life. From the aforementioned problems, it can be seen that what we need to develop now is the teaching approaches being used in Thai schools, only focusing on students' memories. Knowledge is important, but students' knowledge retention and the abilities to authentically use the acquired knowledge are far more important. In the $21^{\text {st }}$ century, most scholars around the world pay attention to how students can learn and retain what they have learnt, and for this reason, collaborative and cooperative learning is the center of their interests. According to Gokhale (1995), working in small groups can encourage learners' knowledge enhancement because they are able to exchange and share ideas to find out a solution to solve such tasks together. This is a real promotion in terms of students' interaction and collaboration through positive independence, leading to their expected learning outcomes (Johnson and Johnson, 1989; Hermann, 2013). Due to the positive effects on collaborative approach, a number of school teachers teaching various subjects utilize it in their classrooms. Gull and Shehzad (2015) state that cooperative learning is a teaching approach that really helps learners understand the contents as it emphasizes the improvement of cognition based on students' active participation with classmates. To make this teaching method more effective, Johnson and Johnson (2009) propose five basic elements, which teachers should carefully look into, namely positive independence, promotive interaction, individual accountability, teaching of interpersonal and social skills, and quality of group processing. Besides, in consistence with Johnson and Johnson, Slavin (1995) mentions four major perspectives that are supposed to be seen from collaborative and cooperative learning, which are motivational perspectives, social cohesion perspectives, cognitive perspectives, and developmental perspectives. To clarify, all the perspectives as stated are related to rewards, social collaboration among students, knowledge gained from such cooperation, and students' critical knowledge development. In accordance with Johnson and Johnson and Slavin, collaborative learning is perceived as an effective teaching approach that can strengthen students' learning achievements and knowledge retention on account that no students can fully receive $100 \%$ of knowledge from what they hear, but they can increase their cognitive comprehension from what they do.

As can be seen, English is a course that requires students' real practice so that they can be using it with fluency. Also, English is an essential skill for all Thai undergraduate students in Thailand. They are expected to communicate English with foreigners effectively after they graduate from universities. Because of this reason, the Language Center of Thepsatri Rajabhat University had offered English 
lessons including four skills: listening, speaking, reading and writing to the firstyear students, but a few years ago a traditional training, which instructors used only textbooks in classes, was employed. The concept of teaching with textbooks did not motivate the students to attend classes much, later on the committee had a meeting and discussed to find a new method of teaching to attract the students. They found out many interesting methods of teaching, and the collaborative learning method. Learning through activities-based learning is one of the popular methods that many instructors use for learning managements. As a result, to help improve the students' English communicative skills at Thepsatri Rajabhat University, a major emphasis of this research was particularly on the development of students' English communicative competence using a collaborative approach. During the classes, collaborative activities, considered as provided experiences for learners, were used to encourage students' participation with their friends through English communicative tasks. Apart from developing their English cognition, based on the use of collaborative activities, their attitudes as well as a need for autonomous learning were mentally enhanced, which could be a further long-term English learning for students.

\section{PURPOSES OF THE RESEARCH}

In this research, the purposes were as follows:

1. To compare the English communicative competence before and after learning through collaborative learning.

2. To identify the satisfactory attitudes of the students towards English language and collaborative learning.

\section{RESEARCH FRAMEWORK}

This research aimed to enhance English communicative competence which related to nine lessons (Self Introduction, School Schedule, Telling Time, Asking and Giving Information, Food, Leisure, Describing People, Describing Things and Giving Direction) using collaborative learning. The independent variable was the collaborative learning and the dependent variables were higher learning achievement and students' satisfaction. The research framework of the study was shown in figure 1. 


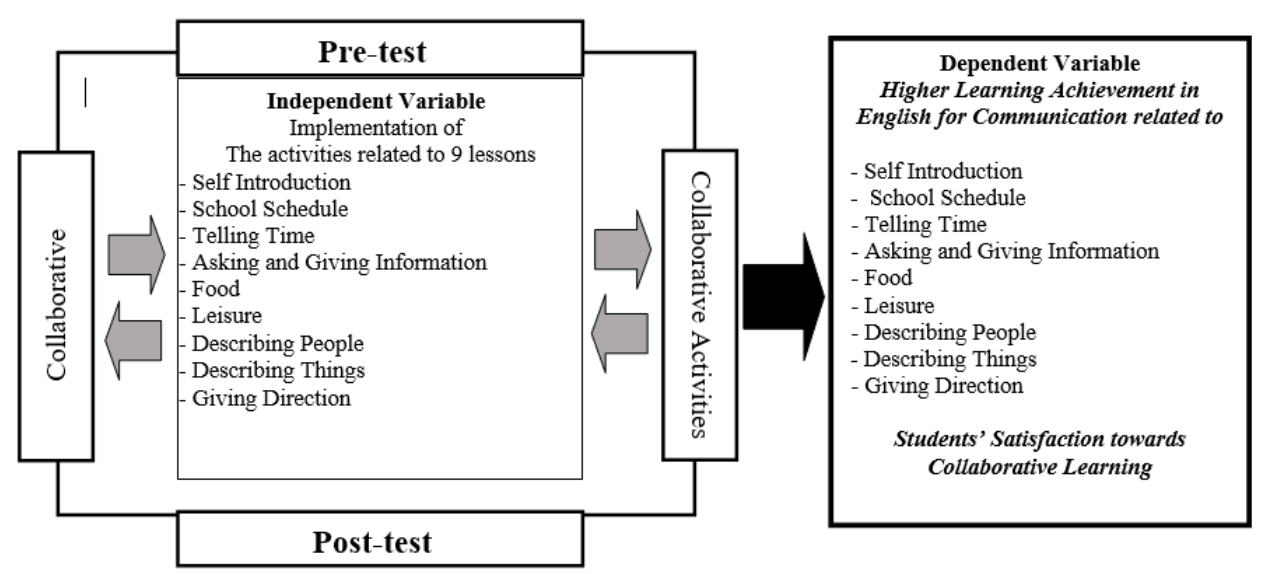

Figure 1 A Research Framework

\section{METHOD}

This present study was an experimental design with pre-test and post-test and the target group of this research were the first-year students from all faculties of Thepsatri Rajabhat University, Lop Buri, Thailand. The procedure of collaborative learning was shown in Table 1.

Table 1 . The 20 hours procedure of collaborative learning

\begin{tabular}{|c|c|c|}
\hline Hour & Topic & Activity \\
\hline 1 & Pre-test & $\begin{array}{l}\text { The students were given a pretest to measure their } \\
\text { communicative competence. }\end{array}$ \\
\hline $2-3$ & $\begin{array}{l}\text { Self- } \\
\text { introduction }\end{array}$ & $\begin{array}{l}\text { Using an icebreaker in order to help students get to } \\
\text { know each other. Then introducing students' names and } \\
\text { help them to know others' names by using role play. }\end{array}$ \\
\hline $4-5$ & $\begin{array}{l}\text { School } \\
\text { schedule }\end{array}$ & $\begin{array}{l}\text { Using a group activity by asking a question about the } \\
\text { school schedule, homework or subject in the university. } \\
\text { Then they have to discuss the topic. "Do they like it or } \\
\text { not?" "What is it about?" "The differences between } \\
\text { high school and university". }\end{array}$ \\
\hline $6-7$ & Telling time & Playing group activity "Minute hand and Hour hand" \\
\hline $8-9$ & $\begin{array}{l}\text { Asking and } \\
\text { giving } \\
\text { information }\end{array}$ & $\begin{array}{l}\text { Learning about asking and giving information. Then } \\
\text { playing "20 questions" game to guess. }\end{array}$ \\
\hline $10-11$ & Food & $\begin{array}{l}\text { Learning food vocabularies and doing a role play as } \\
\text { "Master chef TRU" }\end{array}$ \\
\hline $12-13$ & Leisure & Group discussing about "Leisure activity" \\
\hline $14-15$ & $\begin{array}{l}\text { Describing } \\
\text { people }\end{array}$ & $\begin{array}{l}\text { Playing game "Finding someone who..?" by using } \\
\text { jigsaw technique. }\end{array}$ \\
\hline $16-17$ & $\begin{array}{l}\text { Describing } \\
\text { things }\end{array}$ & Team activity "Finding thing that I described" \\
\hline $18-19$ & $\begin{array}{l}\text { Giving } \\
\text { direction }\end{array}$ & Group activity "Finding a place on map" \\
\hline
\end{tabular}


The students were given a pretest to measure their communicative competence after using collaborative learning.

The participants of the research were 1,471 the first-year students enrolled in the first semester, 2017 academic year, from 6 faculties of Thepsatri Rajabhat University. They were 148 students from the Faculty of Education, 354 students from the Faculty of Humanities and Social Science, 141 students from the Faculty of Industrial Technology, 106 students from the Faculty of Information Technology, 498 students from the Faculty of Management Science and 224 students from the Faculty of Science and Technology.

An 80 multiple choice test of English communicative competence. This test constructed by English lecturers from the analysis of the objectives of the English courses that they have to study in the university. It consisted of nine chapters. After completion to the test construction, the validity of the test was 0.79 .

A questionnaire was used to measure the satisfactory attitudes of the students towards English language and collaborative learning after the experiment. It had five 5-point Likert-type scale items, ranging from 1 "strongly disagree" to 5 "strongly agree". The validity and reliability of the questionnaire were initially determined by two American native speakers.

To find out the effectiveness of English communicative competence and attitudes, statistics including mean scores, standard deviations were used. The answers of the questions were graded with one point if they were correct and zero point if they were wrong. The independent sample t-test was calculated to find the differences between pre-test and post-test.

\section{RESULTS}

This section reports the finding from pre-test and post-test and questionnaire given to students. The results of using collaborative learning were presented in Table 2.

Table 2 The results of students' English communicative competence

\begin{tabular}{|c|c|c|c|c|c|c|}
\hline \multirow{2}{*}{ Faculty } & \multicolumn{2}{|c|}{ Pre-test } & \multicolumn{2}{|c|}{ Post-test } & \multirow[b]{2}{*}{$\mathbf{t}$} & \multirow[b]{2}{*}{ Sig } \\
\hline & Mean & SD & Mean & SD & & \\
\hline Education & 29.35 & 10.893 & 52.51 & 14.124 & -18.33 & .000 \\
\hline $\begin{array}{l}\text { Humanities and } \\
\text { Social Science }\end{array}$ & 39.12 & 13.567 & 64.04 & 15.794 & -33.82 & .000 \\
\hline Industrial Technology & 23.63 & 7.052 & 37.65 & 8.201 & -21.72 & .000 \\
\hline $\begin{array}{l}\text { Information } \\
\text { Technology }\end{array}$ & 18.67 & 7.677 & 49.11 & 11.265 & -29.11 & .000 \\
\hline Management Science & 22.06 & 5.968 & 36.36 & 11.408 & -29.45 & .000 \\
\hline $\begin{array}{l}\text { Science } \\
\text { Technology }\end{array}$ & 23.68 & 6.994 & 47.86 & 11.292 & -38.91 & .000 \\
\hline
\end{tabular}

From Table 2, the students' English communicative competence was overall significantly improved at the .01 level. 


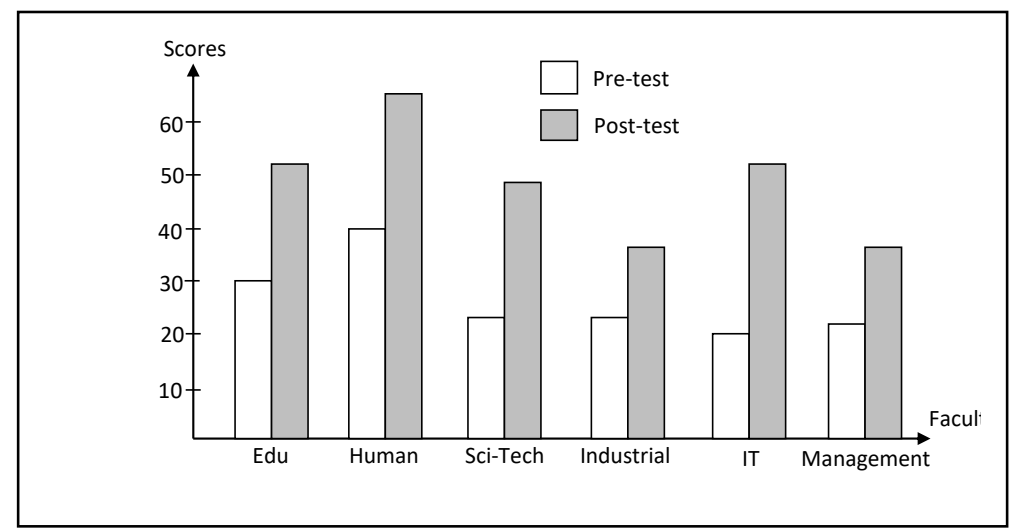

Figure 2 The comparison of students' English communicative competence before and after using collaborative learning

From Figure 2, the data revealed that the comparison of students' English communication competence before and after using collaborative learning. The post-test score was higher than the pre-test score. The highest to the lowest mean score of students' English communicative competence after using collaborative learning were the Faculty of Humanities and Social Science (64.04), Faculty of Education (52.51), Faculty of Information Technology (49.11), Faculty of Science and Technology (47.86), Faculty of Industrial Technology (37.65), Faculty of Management Science (36.36), respectively.

Table 2 The results of students' satisfactory attitudes towards English language and collaborative learning.

\begin{tabular}{lccc}
\hline \multicolumn{1}{c}{ Details } & Mean & SD & Levels of Satisfaction \\
\hline $\begin{array}{l}\text { 1. The contents provided the appropriate } \\
\text { knowledge with the university life. }\end{array}$ & 4.60 & 0.50 & Very high \\
$\begin{array}{l}\text { 2. The appropriateness of the activities to learn } \\
\text { and develop English communication } \\
\text { competence. }\end{array}$ & 4.66 & 0.49 & Very high \\
$\begin{array}{l}\text { 3. The student can apply knowledge to self- } \\
\text { development and further studies in the } \\
\text { university. }\end{array}$ & 4.63 & 0.53 & Very high \\
$\begin{array}{l}\text { 4. The attitude towards the English language } \\
\text { after training }\end{array}$ & 4.64 & 0.50 & Very high \\
5. The satisfaction towards the English language \\
training
\end{tabular}

The results showed that the students had the highest level of satisfaction with the conduct of collaborative learning. The highest level of students' satisfaction were the satisfaction towards the English language training (4.67), the appropriateness of the activities to learn and develop English communication competence (4.66), the attitude towards the English language after training (4.64), the student can apply knowledge to self-development and further studies in the university (4.63), and the contents provided the appropriate knowledge with the university life (4.60), respectively. 


\section{DISCUSSIONS}

According to the results of using collaborative learning in this training, even the subject of the study was large, the study revealed positive outcome both in terms of the English communicative competence and the satisfactory attitudes of the students towards English language. The students were satisfied by worked together and shared effective ideas to the classroom activity. The research results were related to the study of Felix-Aguelo (2017) that enhanced student's English language competencies in speaking, listening, reading and writing skills of students and motivated students to collaborate with other students. Al-Tamimi and Attamimi (2014) provided a support that applying CL techniques can improve student's speaking and attitudes as well. In addition, collaborative activities, provided experiences for learners and used to encourage students' participation with their friends through English communicative tasks. Moreover, Gocer (2010) stated that one of meaningful activities was jigsaw technique which gave positive effect on students' learning process. In addition, Srikote (2012) applied collaborative learning in the class and results revealed that the target students developed their English comprehension in terms of reading, learning vocabularies and writing. Moreover, for the lecturers aimed to help students learn collaboratively, then they had chances to understand students' needs and know how to assist their students' learning together (Chen, 2018).

\section{CONCLUSION}

Collaborative learning enchanted higher levels of student's English communicative competence and the satisfactory attitudes of the students at Thepsatri Rajabhat University towards English language after training in the positive way. The lecturers' roles aimed to support the students to think, share and discuss during the training then they could adapt their knowledge with the collaborative activities in 20 hours of the training period. Therefore, the present findings highly recommended using the collaborative learning to develop students' communicative competence, which could be an effectiveness of English learning for students.

\section{ACKNOWLEDGEMENTS}

The author would like to express my deep gratitude to the TRU language center team for supporting all the useful information and planning the training procedures together. Moreover, I would like to take this opportunity to thank the language center team who dedicated the valuable time and helpful comments and ideas throughout the process of the paper.

\section{REFERENCES}

Al-Tamimi, N. O. M. and Attamimi, R. A. (2014). Effectiveness of Cooperative Learning in Enhancing Speaking Skills and Attitudes towards Learning English. International Journal of Linguistics, 6(4), 27-41. 
Chen, Y. (2018). Perceptions of EFL College Students toward Collaborative Learning. English Language Teaching, 11(2), 1-4.

Crystal, D. (2012). English as a Global Language (Cambridge University Press, England, 2012), pp. 11.

Felix-Aguelo, R. (2017). Enhancing students' language competencies through collaborative learning. Paper presented at the Online Proceedings of the International Conference: DRA: 3-19th ESEA.

Gocer, A. (2010). A comparative research on the effectivity of cooperative learning method and jigsaw technique on teaching literary genres. Educational Research and Reviews, 5(8), 439-445.

Gokhale, A. A. (1995). Collaborative Learning Enhances Critical Thinking. Journal of Technology Education, 7(1), 22-30.

Gull, F., \& Shehzad, S. (2015). Effects of Cooperative Learning on Students' Academic Achievement. Journal of Education and Learning, 9(3), 246-255.

Herrmann, K. J. (2013). The impact of cooperative learning on student engagement: Results from an intervention. Active Learning in Higher Education, 14(3), 175-187.

Johnson, D. W., \& Johnson, R. T. (1989). Cooperation and Competition: Theory and Research. Edina, Minnesota: Interaction Book Company.

Johnson, D. W., \& Johnson, R. T. (2009). An Educational Psychology Success Story: Social Interdependence Theory and Cooperative Learning. Educational Researcher, 38(5), 365-379.

Slavin, R. E. (1995). Research on Cooperative Learning and Achievement: What We Know, What We Need to Know. Retrieved from

Srikote, S. (2013). Learning English through Collaboration: A Case Study at Mahachulalongornrajavidyalaya University, Loei Buddhist College. Procedia-Social and Behavioral Sciences, 88, 274-281. 